\title{
Spectrophotometric Determination of Manganese in Steels by On-Line Electrochemical Oxidation
}

\author{
Tatiana. D. Saint'Pierre ${ }^{a}$, Roldão R.U. de Queiróz ${ }^{a}$, Ivan G. de Souza $^{a}{ }^{*}$, \\ and José A. Gomes Neto ${ }^{b}$ \\ ${ }^{a}$ Departamento de Química, Universidade Federal de Santa Catarina, C.P. 476, \\ 88040-900 Florianópolis - SC, Brazil \\ ${ }^{b}$ Departamento de Química Analitica, Instituto de Química - UNESP, C.P. 355, \\ 14800-900 Araraquara - SP, Brazil
}

Received: October 28, 1996

\begin{abstract}
É proposto um sistema de análise química por injeção em fluxo para a deteminação espectrofotométrica de manganês em aços baseado no efeito catalítico da $\mathrm{Ag}(\mathrm{I})$ na oxidação em linha de $\mathrm{Mn}$ (II) a Mn(VII) sobre uma superfície eletródica de platina. Após a injeção simultânea de amostra e eletrólito na célula eletroquímica, a mistura era homogeneizada por bolhas de ar e os íons permanganatos gerados eram monitorados a $545 \mathrm{~nm}$. As alturas dos sinais transientes obtidos refletiam a concentração do manganês na amostra. Foram investigados os principais parâmetros relacionados com os processos coulométricos tais como intensidade de corrente, concentração do mediador, tempo de eletrólise, natureza do eletrólito suporte, bem como aqueles relacionados com a arquitetura do sistema FIA.

O sistema espectrofotométrico proposto possibilitou a determinação de manganês em aços no intervalo de concentrações de 5,00 a $150 \mathrm{mg} \mathrm{L}^{-1}(\mathrm{r}=0,9998)$. Com tempos de eletrólise de $60 \mathrm{~s}$, foram possíveis 20 determinações por hora (R.S.D. $<3 \%$ ). Os resultados da análise aços certificados com o sistema proposto não foram estatisticamente diferentes dos valores certificados e daqueles obtidos pelo método de referência ao nível de $95 \%$ de confiabilidade.

The aim of this work is to propose a flow spectrophotometric procedure for manganese determination in steel based on electrochemical oxidation of $\mathrm{Mn}$ (II) to $\mathrm{Mn}$ (VII) at a Pt electrode surface by means of the catalytic effect of $\mathrm{Ag}(\mathrm{I})$.

The on-line oxidation step was obtained by injecting sample and electrolyte solution directly into an electrolytic cell. After electrolysis, the injectate was homogenized by bubbling air. The permanganate ions produced were passed through the spectrophotometer where absorbance was monitored at $545 \mathrm{~nm}$. Effects of direct current, silver concentration, timing, flow rates, concentration and composition of support electrolyte were investigated. Direct current and silver content manifested themselves as the most relevant parameters. For determination of manganese in the 5.00 $150 \mathrm{mg} \mathrm{L}^{-1}$ range $(\mathrm{r}=0,9998)$ and $60 \mathrm{~s}$ electrolysis time, the sample throughput was $20 \mathrm{~h}^{-1}$. Accuracy was assessed by analyzing ten steel standard reference materials. Results are precise (R.S.D. $<3 \%$ ) and in agreement with certified values of reference materials and with standard methods at $95 \%$ confidence level.
\end{abstract}

Keywords: manganese, FIA, spectrophotometry, coulometric reagent generation

\section{Introduction}

There are several analytical techniques for manganese determination in steel and ferroalloy samples: flame atomic absorption spectrometry (FAAS) ${ }^{1}$, electrothermal atomic absorption spectrometry (ETAAS) ${ }^{2}$, inductively coupled plasma optical atomic spectrometry (ICP-OES) $)^{3}$, induc- 
tively coupled plasma emission atomic spectrometry (ICP$\mathrm{AES})^{4}$, inductively coupled plasma mass spectrometry $(\mathrm{ICP}-\mathrm{MS})^{5}$, molecular absorption spectrophotometry (UVVIS) ${ }^{6}$, neutron activation analysis (NAA) ${ }^{7}$, X-Ray fluorescence $(\mathrm{XRF})^{8}$ and voltametry (ARV) ${ }^{9}$. However, molecular absorption spectrophotometry is a very attractive tool for the analysis of steel samples due to its operational simplicity, low cost, high selectivity and automation potential ${ }^{10}$. Notwithstanding, there are several automated methods for manganese determination based on formation of coloured metallic complexes ${ }^{11,12}$ or on catalytic effect of manganese upon several redox systems ${ }^{13,14}$. The classical spectrophotometric method for determining manganese in steel and ferroalloys based on the production of permanganate by using strong oxidizing agents (e.g. periodate, persulphate), acidic media and high temperature has proved extremely useful ${ }^{15}$. Additionally, several works have already reported the electrocatalytic effect of silver ion on this oxidation ${ }^{16-19}$. The long warming times and the high strong acid media required for manganese oxidation ${ }^{14,15}$ are the Achilles heel of this procedure in flow-injection analysis. This problem can be circumvented by exploiting the approach of coulometric reagent generation. This study reports on a new method for determining manganese in steels and ferroalloy samples by using silver(II) as catalyst for on-line electrochemical generation of permanganate in a flow-injection system.

\section{Experimental}

\section{Instrumentation}

A B342 II Micronal spectrophotometer provided with flow cell ( $100 \mu \mathrm{L}$ inner volume, $10 \mathrm{~mm}$ optical path), a RB 101 ECB strip chart recorder, a B-332 Micronal peristaltic pump furnished with Tygon pumping tubes, two homemade injector-commutators, polyethylene tubing $(0.7 \mathrm{~mm}$ i.d.) and accessories were used. The electrochemical cell was machined in a PMMA acrylic resin (Perspex, ICI). The cell is shown in Fig. 1 and consists of a $1 \mathrm{~mL}$ well $(24 \mathrm{~mm}$ deep, $10 \mathrm{~mm}$ i.d.) machined in a resin block. A $2.0 \mathrm{~mm}$ hole on the bottom of the well was made for inlet of electrolyte solution and outlet of electrolysis product. A $1.0 \mathrm{~mm}$ hole to purge the gases produced in the electrolytical process was located at the top of the cell. The cathode was a platinum helical wire which was separated from the test solution by a glass tube. The contact between the solutions was made by a Vycor seal situated at the bottom of the glass tube. The anode was a platinum cylinder gauze $\left(5 \mathrm{~cm}^{2}\right)$ rolled up around the Vycor glass tube. Electric contacts were made by means of platinum wires.

A homemade current source was built to supply current from 20 to $1200 \mathrm{~mA}$. Well defined pulses were assured by using an IC-555 timer ${ }^{20}$.

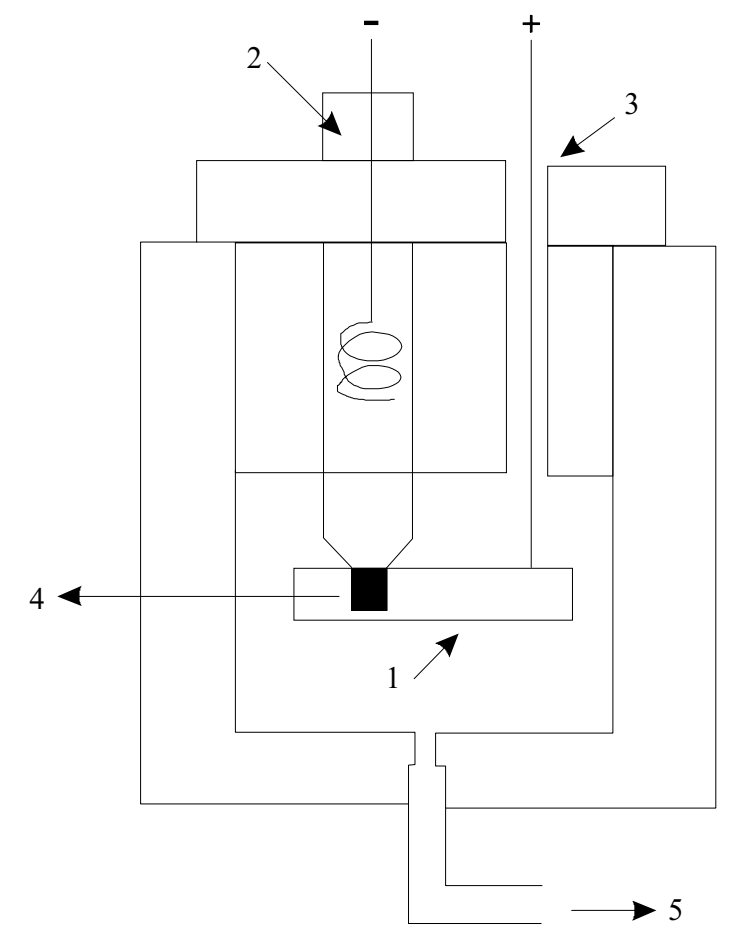

Figure 1. Schematic representation of the electrochemical cell. Main body machined in PMMA resin comprises anode (1), cathode (2), gas outlet (3), ionic contact (4, Vycor seal) and inlet or outlet of solutions (5).

\section{Reagents, standards and samples}

All chemicals used were analytical-reagent grade and distilled-deionized (Milli-Q) water. Catholyte was a 20\% (v/v) $\mathrm{H}_{2} \mathrm{SO}_{4}$ solution.

Manganese(II) stock solution was $1000 \mathrm{mg} \mathrm{L}^{-1}$ in 0.5 mol L ${ }^{-1} \mathrm{HNO}_{3}$ (Titrisol, Merck). The analytical solutions $\left(0.00 ; 50.0 ; 80.0 ; 100 ; 130 ; 150 \mathrm{mg} \mathrm{L}^{-1}\right.$ of $\left.\mathrm{Mn}\right)$ were prepared by dilution of the stock solution. Perchloric acid and iron(III) were added to these solutions in order to match the iron content in the diluted sample digests $\left(10 \mathrm{mg} \mathrm{L}^{-1}\right)$.

The dissolution of the certified steel samples was performed by mixing $1.0000 \mathrm{~g}$ of the sample and $20 \mathrm{~mL}$ of $50 \%(\mathrm{v} / \mathrm{v}) \mathrm{HNO}_{3}$ solution and 15 to $30 \mathrm{~mL}$ of concentrated $\mathrm{HClO}_{4}$ solution. The mixture was heated up to eliminate nitrous fumes. The final solution was diluted to $100 \mathrm{~mL}$ with water.

The $1.0 \times 10^{-4} \mathrm{~mol} \mathrm{~L}^{-1} \mathrm{AgNO}_{3}$ electrolyte solution was prepared in $5 \%(\mathrm{v} / \mathrm{v}) \mathrm{H}_{2} \mathrm{SO}_{4}$ solution.

\section{Procedure}

The flow diagram used in this work is shown in Fig. 2. When the injector-commutator $\mathrm{IC}_{1}$ was in the specified position, $\mathrm{L}_{1}$ loop $(60 \mathrm{~cm})$ and $\mathrm{L}_{2}$ loop $(30 \mathrm{~cm})$ selected the electrolyte, $\mathrm{E}$, and the sample, $\mathrm{S}$, respectively and were mixed with the carries stream $\mathrm{C}_{1}$ (air, $3.8 \mathrm{~mL} \mathrm{~min}^{-1}$ ). The established sample and electrolyte zones were carried to- 


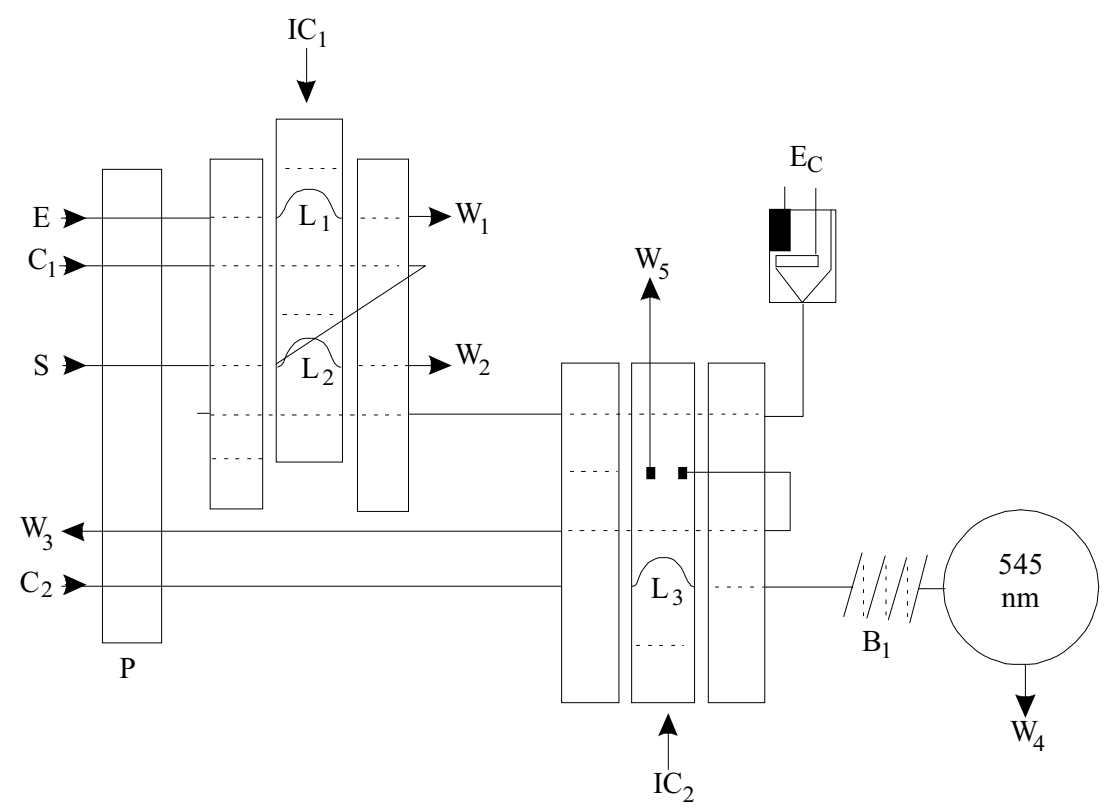

Figure 2. Flow set up. This arrangement was used for characterization of the electrochemical cell and implementation of the method for the manganese determination. $\mathrm{IC}_{1}, \mathrm{IC}_{2}$ : injector-commutators; $\mathrm{C}_{1}$ : carrier stream of electrolyte and sample (air, $3.8 \mathrm{~mL} \mathrm{in}^{-1}$ ); E: electrolyte; $\mathrm{S}$ : sample; $\mathrm{C}_{2}$ : analyte carrier stream (water, $\left.3.8 \mathrm{~mL} \mathrm{in}^{-1}\right)$; $\mathrm{L}_{1}, \mathrm{~L}_{2}$, L3: sampling loops (60, 30, $60 \mathrm{~cm}$ ); B: homogenization coil (50 cm); EC: electrolysis cell; D: detector (545 nm); PP: peristaltic pump; W: waste.

wards the electrochemical cell. To achieve this condition, the injector-commutator $\mathrm{IC}_{2}$ was operated as shown in Fig. 2. After the sample and electrolyte solutions were delivered into the electrolytic cell, a pulse of electric current of 100 $\mathrm{mA}$ during $60 \mathrm{~s}$ was applied. This was attained by triggering the timer control of the current source supply. The production of permanganic acid under homogenized conditions by bubbling air takes place inside the cell. Afterwards, the injector-commutator $\mathrm{IC}_{2}$ was switched to another position and a permanganate volume was selected by the $\mathrm{L}_{3}$ loop ( 60 $\mathrm{cm}$ ) and inserted into the carrier stream $\mathrm{C}_{2}$ (water, $3.8 \mathrm{~mL}$ $\min ^{-1}$ ). During the $\mathrm{L}_{3}$ sampling, the injector-commutator $\mathrm{IC}_{1}$ was switched back. Passage of the electrolyzed sample through the flow cell resulted in a transient absorbance monitored at $545 \mathrm{~nm}$ and recorded as a peak with height proportional to the manganese content in the sample. After discarding the solution from the electrochemical cell, the injector-commutator $\mathrm{IC}_{2}$ was switched back to the position specified in Fig. 2, starting another cycle.

In order to obtain a high permanganate generation, the main parameters related to the efficiency of the electrochemical process such as composition and concentration of acid, silver concentration, electrolyte concentration, current intensity and timing were investigated. Electrolysis was carried out either in perchloric, phosphoric, nitric or sulfuric acid in the $0.5-3.0 \mathrm{~mol} \mathrm{~L}^{-1}$ range.

The influence of applied current was studied within a $20-160 \mathrm{~mA}$ interval with a $100 \mu \mathrm{g} \mathrm{mL}{ }^{-1}$ of $\mathrm{Mn}$.
Optimization of physical, chemical and hydrodynamic parameters involved in the system performance was carried out by the univariate method. Table 1 shows the ranges over which each parameter was investigated.

\section{Results and Discussion}

Silver(II) is a very powerful oxidant and undergoes rapid reactions with a wide range of inorganic and organic species ${ }^{16-19}$. At a polarized platinum electrode and in highly acid medium, $\mathrm{Ag}^{+} / \mathrm{Ag}^{2+}$ couple is almost reversible and silver(I) can be considered an effective catalyst in the anodic oxidation of manganese(II). Solid particles formation was observed in the absence of $\mathrm{Ag}^{+}$. According to the Cartwright mechanism ${ }^{21}$, manganese dioxide is the main species produced during electrolysis:

$$
\begin{aligned}
& \mathrm{Mn}(\mathrm{II}) \longrightarrow \mathrm{Mn}(\mathrm{III})+\mathrm{e}^{-} \\
& \mathrm{Mn}(\mathrm{III})+2 \mathrm{H}_{2} \mathrm{O} \longrightarrow \mathrm{MnO}(\mathrm{OH})_{(\mathrm{s})}+3 \mathrm{H}^{+} \\
& \mathrm{MnO}(\mathrm{OH})_{(\mathrm{s})} \longrightarrow \mathrm{MnO}_{2}(\mathrm{~s})+\mathrm{H}^{+}+\mathrm{e}^{-}
\end{aligned}
$$

The presence of solid particles in the analytical path caused severe memory effects, drop in sensitivity and occasionally flow-line clogging. With relatively lottle manganese dioxide formation and $60 \mathrm{~s}$ electrolysis time, electrical current intensities higher than $100 \mathrm{~mA}$ should be applied to guarantee the formation of a small amount of permanganate. These results were in agreement with those commented by Comminellis and co-workers ${ }^{16-18}$. This 
Table 1. Optimization of variables.

\begin{tabular}{llcc}
\hline Type & Variable & Range studied & Selected value \\
\hline Physical & Temperature $/{ }^{\circ} \mathrm{C}$ & 25 & 25 \\
& Current $/ \mathrm{mA}$ & $20-160$ & 100 \\
FIA & Flow rate $/ \mathrm{mLmin}^{-1}$ & 3,8 & 3,8 \\
& Reactor length $/ \mathrm{cm}$ & $20-100$ & 50 \\
& Injected volume/ $\mu \mathrm{L}$ & $50-150$ & 60 \\
\hline Chemical & Eletrolyte $/ \mathrm{mol} \mathrm{L}^{-1}$ & $0.5-3.0$ & 1.0 \\
& Mediador & $1 \times 10^{-4}-1 \times 10^{-2}$ & $1 \times 10^{-4}$ \\
\hline
\end{tabular}

drawback was circumvented by adding silver nitrate to the electrolyte (E, Fig. 2). In the presence of $10^{-4} \mathrm{~mol} \mathrm{~L}^{-1}$ $\mathrm{AgNO}_{3}$ a minimum amount of solid and a "pinkish" solution due to permanganate formation were observed. These results show that the presence of silver is a parameter of utmost relevance. When the silver nitrate concentration was varied from $1 \times 10^{-4}$ to $1 \times 10^{-2} \mathrm{~mol} \mathrm{~L}^{-1}$, the analytical signals increased proportionally, confirming that silver(I) was a very effective catalyst in the oxidation of manganese(II) to manganese(VII), according to Eqs. 4 and 5:

$$
\begin{aligned}
& 5 \mathrm{Ag}^{+} \longrightarrow 5 \mathrm{Ag}^{2+}+5 \mathrm{e}^{-} \\
& 5 \mathrm{Ag}^{2+}+\mathrm{Mn}^{2+}+12 \mathrm{H}_{2} \mathrm{O} \underset{\mathrm{MnO}_{4}^{-}+5 \mathrm{Ag}^{+}+8 \mathrm{H}_{3} \mathrm{O}^{+}}{\longrightarrow}
\end{aligned}
$$

The divalent silver species oxidized manganese(II) to permanganate in the bulk solution. The reagent was then coulometrically generated at the anode surface according to step (4). Thus, $\operatorname{Ag}(\mathrm{I})$ acted as a "current carrier" in the $\mathrm{Mn}(\mathrm{II})$ oxidation $^{22-23}$. Since for $1 \times 10^{-4} \mathrm{~mol} \mathrm{~L}^{-1} \mathrm{AgNO}_{3}$ the analytical curve was linear up to $150 \mathrm{mg} \mathrm{L}^{-1}$ of $\mathrm{Mn}$, that silver concentration was selected for further experiments.

Concerning acid composition, when the reaction was performed in presence of perchloric or phosphoric acid, lower analytical signals were recorded. In the former case, the reduction in signal was attributed to the oxygen evolution at the anode surface, reducing the current efficiency of the net process. For the later, the signal reduction was attributed to the $\mathrm{Mn}$ (II) complexation by phosphate. Higher signals were observed for nitric and sulfuric acid. Since the precision and the sensitivity were better for sulfuric acid, this acid has been chosen for further experiments. Concentrations of $\mathrm{H}_{2} \mathrm{SO}_{4}$ were investigated in the range 0.5 to 3.0 mol L ${ }^{-1}$ and showed two distinct behaviors. For acid concentrations $<1.0 \mathrm{~mol} \mathrm{~L}^{-1}$, the conversion of $\mathrm{Mn}$ (II) to permanganate was slow, increasing the sensitivity. The displacement of the chemical equilibrium according (2) and (3) can remove manganese from solution as the oxide, thus reducing sensitivity. The reduction in analytical signal was ascribed to hydrolysis of $\mathrm{Mn}(\mathrm{III})^{16,18}$. For a sulfuric acid concentration higher than $2.0 \mathrm{~mol} \mathrm{~L}^{-1}$, the yield of permanganate formation was poor. This was attributed to the combined effects of equilibrium displacement towards $\mathrm{Mn}(\mathrm{II})$ (Eq. 5) and masking effects of manganese ions due to high sulfate content. These results are in agreement with the literature ${ }^{16,18}$. It should be commented that the use of highly acidic solutions in flow-spectrophotometry may cause a pronounced Schlieren effect ${ }^{24}$ and temperature rise. As the conversion of $\mathrm{Mn}$ (II) to $\mathrm{MnO}_{4}{ }^{-}$is temperature dependent and as a compromise between system stability, reagent consumption, least temperature variation, and in order to avoid the use of special pumping tubes, a $1 \times 10^{-4}$ mol L ${ }^{-1} \mathrm{AgNO}_{3}$ plus $1.0 \mathrm{~mol} \mathrm{~L}^{-1} \mathrm{H}_{2} \mathrm{SO}_{4}$ solution was selected.

The influence of applied current on the permanganate formation efficiency was evaluated by processing a $100 \mathrm{mg}$ $\mathrm{L}^{-1} \mathrm{Mn}(\mathrm{II})$ standard solution in the $20-160 \mathrm{~mA}$ current interval. Analysis of Fig. 3 reveals that the relationship between analytical signal and current intensity was linear. For current intensity greather than $100 \mathrm{~mA}$, powerful gas evolution was observed. As a result, the solution homogenization at the internal cell compartment during the electrolysis was defective. At high current density, side

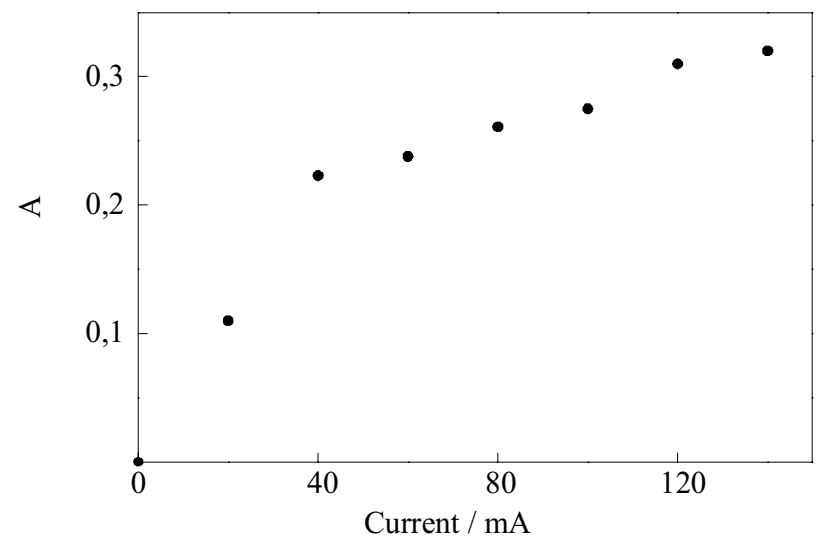

Figure 3. Influence of current intensity. Curve corresponds to electrolysis of $100 \mathrm{mg} \mathrm{L}^{-1}$ of Mn at different currents during $60 \mathrm{~s} . \mathrm{E}=1 \times 10^{-4} \mathrm{~mol} \mathrm{~L}^{-1}$ $\mathrm{AgNO}_{3}$ plus $1 \mathrm{~mol} \mathrm{~L}^{-1} \mathrm{H}_{2} \mathrm{SO}_{4}$ plus $10 \mathrm{mg} \mathrm{L}^{-1}$ of Fe. $\mathrm{A}=$ absorbance $(\lambda=$ $525 \mathrm{~nm}$ ). 


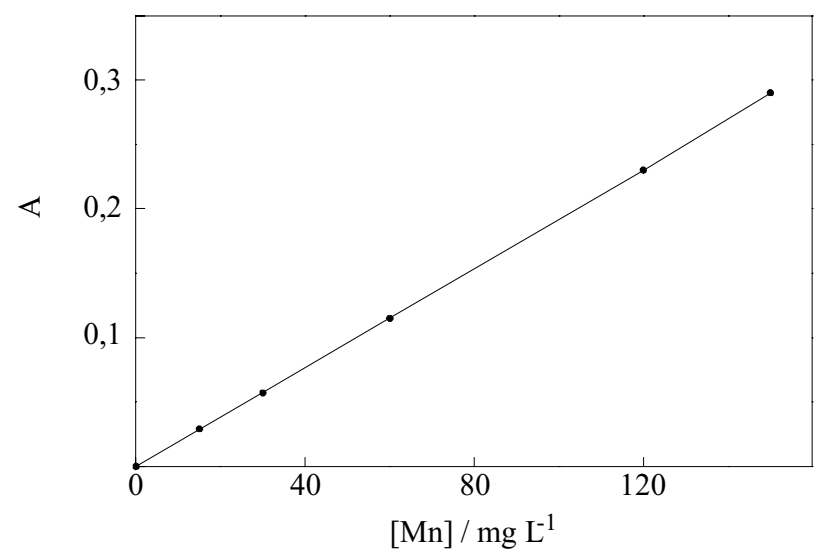

Figure 4. Analytical curve for manganese determination. Curve corresponds to 60 -s electrolysis of five analytical solutions $\left(50-150 \mathrm{mg} \mathrm{L}^{-1}\right.$ of $\mathrm{Mn}$ at $100 \mathrm{~mA} . \mathrm{E}=1 \times 10^{-4} \mathrm{~mol} \mathrm{~L}^{-1} \mathrm{AgNO}_{3}$ plus $1 \mathrm{~mol} \mathrm{~L}^{-1} \mathrm{H}_{2} \mathrm{SO}_{4}$ plus $10 \mathrm{mg} \mathrm{L}^{-1}$ of $\mathrm{Fe} ; \mathrm{A}=$ absorbance $(\lambda=525 \mathrm{~nm})$. $\mathrm{IC}_{1}$ in the injection position corresponds to $\mathrm{t}=0 \mathrm{~s}$.

reactions due to water electrolysis increase due to anodic deposition of $\mathrm{AgO}$ which has high electrocatalylic properties for oxygen evolution. The permanganate formation in this potential region is governed by oxidation in the presence of $\mathrm{AgO}$ at the anode surface. With current intensities higher than $100 \mathrm{~mA}$, both the oxygen evolution and anodic $\mathrm{AgO}$ deposition were favored. At lower currents the side reactions were minimized. This improved the current efficiency for permanganate formation. A current intensity of $100 \mathrm{~mA}$ was fixed for further tests.

Since only large amounts of coloured metal ions (e.g. $\mathrm{Ni}^{2+}, \mathrm{Cr}^{3+}, \mathrm{Co}^{2+}, \mathrm{Cu}^{2+}$ ) cause interference, the influence of these elements, commonly present in steel samples, was investigated. Cobalt and copper in up to 200-fold excess and up to 100 -fold excess of nickel did not interfere. A
40 -fold excess of $\mathrm{Cr}$ can be tolerated in samples with $<0.1 \%$ of Mn. With regards to chromium(III), its interference was eliminated with a previous oxidation of $\mathrm{Cr}(\mathrm{III})$ to $\mathrm{Cr}(\mathrm{VI})$ by using perchloric acid during the sample treatment. The residual color of the blank was subtracted from samples. The negative interference due to perchloric acid was eliminated by adding this acid in samples and standard solutions. Matrix interference by iron was minimized by preparing the analytical solutions with iron to match the iron content of the sample solutions ${ }^{25}$. It should be commented that for special sample lots, chorocomplex formation is an effective alternative procedure for previous separation of $\mathrm{Mn}$ from $\mathrm{Co}, \mathrm{Ni}, \mathrm{Fe}, \mathrm{Cu}$ on anion- and cation-exchange columns.

\section{Features of the method}

After system dimensioning, analytical solutions within the $5.00-150 \mathrm{mg} \mathrm{L}^{-1}$ range (Fig. 4) were injected in triplicate. The linear range was suitable for applying the method to the determination of manganese in steel samples. The precision was studied at the center of the linear range. The relative standard deviations were estimated as $2.12 \%$ for $73,6 \mathrm{mg} \mathrm{L}^{-1}$ of $\mathrm{Mn}$ in the sample digest after ten sequential injections. Accuracy was assessed by analyzing steel reference materials from Villares metallurgical industries (São Carlos, SP, Brazil), IPT (Technological Research Institute, São Paulo, Brazil) and NBS, and the results are shown in Table 2. The results obtained with the proposed procedure were not statistically different from those obtained with the classical method at $95 \%$ confidence level (t-test approach). For $5.00-150 \mathrm{mg} \mathrm{L}^{-1}$ of $\mathrm{Mn}$ and $60 \mathrm{~s}$ electrolysis time, a throughput of 20 samples per hour was attained, which gives a significant economy in sample and

Table 2. Comparative results. Manganese contents $[\%(\mathrm{w} / \mathrm{w})]$ in standard reference materials (SRM) determined by the proposed system (A) and by the standard method $(\mathrm{B})^{1,2}$. Uncertainties at the $\mathrm{A}$ and $\mathrm{B}$ columns are estimates of standard deviations based on triplicate analysis.

\begin{tabular}{lccc}
\hline SRM & $\mathrm{A}$ & $\mathrm{B}$ & Certified value \\
\hline AISI 1040* & $0.736 \pm 0.012$ & $0.760 \pm 0.018$ & $0.776 \pm 0,003$ \\
EURO 177.1* & $0.495 \pm 0.005$ & $0.523 \pm 0.006$ & $0.519 \pm 0,002$ \\
EURO 178.1* & $0.641 \pm 0.011$ & $0.652 \pm 0.014$ & $0.672 \pm 0,003$ \\
IPT 11A** & $0.436 \pm 0.003$ & $0.435 \pm 0.00572$ & $0.439 \pm 0,003$ \\
IPT 13A** & $0.728 \pm 0.0114$ & $0.717 \pm 0.011$ & $0.723 \pm 0,005$ \\
IPT 16** & $0.791 \pm 0.015$ & $0.728 \pm 0.009$ & $0.737 \pm 0,005$ \\
IPT 39** & $0.372 \pm 0.002$ & $0.337 \pm 0.007$ & $0.340 \pm 0,003$ \\
IPT 43* & $1.426 \pm 0.083$ & $1.406 \pm 0.111$ & $1.420 \pm 0,006$ \\
IPT 55** & $0.836 \pm 0.009$ & $0.918 \pm 0.015$ & $0.923 \pm 0,008$ \\
NBS 196 & $0.569 \pm 0.007$ & $0.548 \pm 0.010$ & $0.554 \pm 0,001$ \\
\hline
\end{tabular}

*SRM from Villares metallurgical industries (dilution 1:100).

**SRM from Technological Research Institute. 
reagent consumption if compared to other automated or manual procedures for manganese determination.

\section{Conclusions}

Permanganate was electrochemically generated by using two polarized platinum electrodes and $\mathrm{Ag}$ (II) as catalyst in a flow-injection system. The approach can be efficiently applied to flow spectrophotometric determination of manganese in large scale analysis of steel samples.

\section{Acknowledgments}

The authors appreciated the partial support from Conselho Nacional de Desenvolvimento Científico e Tecnológico. I.L. Mattos is thanked for critical comments.

\section{References}

1. Welz, B. Atomic Absorption Spectrometry, VCH, Germany, 1985, p. 394

2. Bendito, C. Fresenius J. Anal. Chem. 1994, 348, 353.

3. Hiddman, L.; Vebbing, J.; Ciocan, A.; Dessene, O.; Niemax, K. Anal. Chim. Acta 1993, 283, 152.

4. Ren, J.M.; Salin, E.D. Spectrochim. Acta 1994, 49B, 567.

5. Holland, G.; Eaton, A.N. In Applications of Plasma Source Mass Spectrometry, Royal Society of Chemistry, Great Britain, 1990, p. 23.

6. Zolotov, Yu. A.; Monosanova, E.I.; Zhalovannaya, S.V.; Ryukarev, S.S. Anal. Chim. Acta 1995, 308, 386.

7. Nguyen, V.A. J. Radioanal. Nucl. Chem 1994, 187, 67.

8. Metz, U.; Hoffman, P.; Weinbruch, S.; Ortner, H.M. Mikrochim. Acta 1994, 117, 95.

9. Wang, J.; Lu, J. Talanta 1995, 42, 331.
10. Ruzicka, J.; Hansen, E.H. In Flow Injection Analysis, Wiley Interscience, New York, 1988, p.336.

11. Giné, M.F.; Zagatto, E.A.G.; Bergamin Filho, H. Analyst 1979, 104, 371.

12. Betteridge, D.; Douglas, E.L.; Fields, B.; Sweet, P.; Deam, D.R. Anal. Proc. 1981, 18, 26.

13. Mottola, H.A.; Pérez-Bendito, D. Anal. Chem. 1996, 68, 257R.

14. Mesquita, M.; Jacinto, A.O.; Zagatto, E.A.G.; Antônio, R.F. J. Braz. Chem. Soc. 1990, 1, 28.

15. Lingane, J.J.; Collat, J.W. Anal. Chem. 1950, 22, 166.

16. Comninellis, C.; Petitpierre, J.P. Electrochim. Acta 1991, 36, 1363.

17. Boardman, D.W.; Lin-Cai, J.; Pletcher, D. J. Electroanal. Chem. 1983, 149, 49.

18. Comninellis, C.; Plattner, E. J. Eletrochem. Soc: Electrochem. Science and Techn. 1982, 129, 749.

19. PetitPierre, J.P.; Comninellis, C.; Plattner, E. Electrochim. Acta 1990, 35, 281.

20. Linear Circuits Data Book. Texas Instruments, 1987, p.5.21.

21. Paul, R.L.; Cartwright, J. Electroanal. Chem. 1986, 201, 113.

22. Fleishmann, M.; Pletcher, D.; Rafinski, A. J. Applied Electrochem. 1971, 1, 1.

23. Jow, J.J.; Chou, T.C. J. Appl. Electrochem. 1988, 18, 298.

24. Fang, Z. In Flow Injection Separation and Preconcentration, VHC, New York, 1993, p.38.

25. Thorburn Burns, D.; Chimpalee, N.; Harriott, M.; Mekillen, G.M. Anal. Chim. Acta 1989, 217, 183.

FAPESP helped in meeting the publication costs of this article 